\title{
3
}

\section{Party registration and political participation: Regulating small and 'micro' parties}

\author{
Norm Kelly
}

In the year before the 2013 federal election, 22 new political parties were registered. Many of these parties did not require their members to be active within the party or to pay fees; members were primarily used to meet registration requirements. The proliferation of these new parties would have been a trivial aside to the 2013 election, except that four went on to win six influential seats in parliament, including two parties that achieved less than 1 per cent in primary vote support. Because of the fine balance in the Senate after the election, where neither the Liberal-National Coalition Government nor the Labor Opposition held a majority of seats, these microparties wielded considerable power in determining contested legislative outcomes. These parties' electoral successes, which were based on a very tight exchange of preferences between many of these new microparties, have resulted in the new parties being accused of 'gaming' the system. ${ }^{1}$

1 For example, see Antony Green (2014) Is It Time for a Fundamental Review of the Senate's Electoral System?, Papers on Parliament No. 62, Canberra: Parliament of Australia, available at: www.aph.gov.au/ / /link.aspx?_id=6EAB2F2521E8462CBBBF9EAE79C5229C\&_z=z; Joint Standing Committee on Electoral Matters (JSCEM) (2014) Interim Report on the Inquiry into the Conduct of the 2013 Federal Election: Senate Voting Practices, Canberra: Parliament of Australia, available at: www.aph.gov.au/Parliamentary_Business/Committees/Joint/Electoral_Matters/2013_ General_Election/Interim_Report. 
The term 'gaming the system' in this context refers to the ability to produce successful election outcomes that do not necessarily correspond to voters' wishes, or to the relative support for the different parties. In fact, what these newer parties have done is utilise the established Senate ticket voting system to their own advantage, thereby outmanoeuvring the major parties that established the system 30 years ago. The major parties had been reluctant to reform the system, despite a growing understanding that Senate results could be 'gamed' in this way. As a result, the major parties suffered at the 2013 election.

This chapter explores the rise of the 'microparty' in Australia and its relationship to federal electoral regulation. It also asks whether Australia's party registration regime has a positive effect on the political participation function of parties discussed in Chapter 1 . The following sections examine the legislative foundation for the regulation of political parties and the environment this has created for participation, both for internal member participation and for external electoral competition. A typology of microparties in the federal context is provided, and party registration trends since the commencement of the regulatory era in 1983 are analysed. This is followed by a discussion of the two-tiered membership threshold, which requires either 500 members or a sole parliamentarian to register a party. The role of regulation to encourage internal party democracy is assessed, as is whether legislators ought to provide controls or incentives - for example, by being more prescriptive on matters to be included in a party's constitution. Finally, an appraisal is provided of relevant aspects of the reform process, from the introduction of the party registration scheme in 1983 to the 2014 recommendations of the Joint Standing Committee on Electoral Matters (JSCEM) and, briefly, the 2016 Senate voting reforms. 


\section{The regulation of political parties}

Political parties have a number of potential roles, including the recruitment of citizens into democratic processes and political activism. ${ }^{2}$ The experience of party regulation in Australia, however, suggests that genuine citizen engagement has been of little consideration. The main reasons given in 1983 for introducing a political party registration scheme at the federal level were to enable parties to access public funding, provide recognition on ballot papers, introduce financial disclosure and reporting requirements, and reduce the level of informal Senate voting by allowing for the distribution of Senate preference votes through registered party tickets. ${ }^{3}$

While it can be argued that a membership threshold creates an uneven playing field for electoral competition, the new legislation at least provided a set of rules that clearly established the requirements for playing the political game. The introduction of this scheme strengthened the role of the existing parties, but also provided a framework with which emergent parties could work. But while providing a framework for party competition, the legislation was largely silent on the question of promoting political participation, allowing parties to carry out this purpose as they saw fit.

The growth and influence of the new microparties, without an obvious corresponding increase in party activism, appear to be an example of political opportunism, but can also be considered a reaction against a party cartel's control of the electoral system. ${ }^{4}$ On one hand, this trend can be seen as indicative of efforts to 'game' the voting system. But gaming the system might also be seen as learning to better

2 Benjamin Reilly, Per Nordlund and Edward Newman (2008) Political Parties in ConflictProne Societies: Encouraging Inclusive Politics and Democratic Development, Tokyo: United Nations University.

3 The single transferable voting system is used to elect Senators. In a normal half-Senate election, six Senators are elected from each of the six States, with a quota being 14.3 per cent of the vote. Two Senators are also elected from each of the two mainland Territories. Parties are able to lodge group voting tickets (GVTs), which direct the preferences for voters who vote for the party 'above the line'. Although voters can choose to direct where their preferences go by voting 'below the line', less than 5 per cent do so, largely because of the complexity and time required to fill out the ballot paper.

4 For example, see Senator John Madigan, in Lenore Taylor (2016) 'Senate Voting Changes: Coalition Wins over Nick Xenophon and Greens', The Guardian, 12 February, available at: theguardian.com/australia-news/2016/feb/12/senate-voting-changes-coalition-wins-over-nickxenophon-and-greens. 
compete within the rules of the system, as laid down by the governing powers. Thus the creation and manoeuvring of newer microparties might be more broadly regarded as a legitimate strategy to break into a political system that has been controlled largely by the two major parties (Labor and the Liberal-National Coalition) for decades. The overriding questions then become: Does the proliferation of parties promote genuine participation of citizens in political debate? Should legislation explicitly encourage such participation? Is this healthy for Australia's democracy?

At a time when political parties in Western democracies, including Australia, are experiencing a decline in membership, ${ }^{5}$ Australia has witnessed this significant increase in the number of parties contesting elections (see Figure 3.1). Could the new parties be filling an identified gap in the spectrum of possibilities for political expression and political participation? Is Australia's party registration regime, combined with the Senate single transferable vote (STV) voting system, doing anything to promote genuine political participation? Or is the growth in the number of parties simply a reflection of political expediency brought about by the inaction of legislators since party registration was introduced in 1983?

Interest in the number of political parties contesting federal elections reached a peak at the 2013 election-primarily because of Senate counts that resulted in two parties that initially received less than 0.04 of a quota in primary votes eventually winning seats. This was achieved primarily by staying ahead of other parties with fewer votes and then receiving their preference allocations. ${ }^{6}$ These results were possible through tightly controlled preference exchanges between several parties, each with a small share of the primary vote, but collectively able to combine to achieve a significant share of the vote. Also of concern was the impact on voters, with electors

5 For example, see Marian Sawer, Norman Abjorensen and Phil Larkin (2009) Australia: The State of Democracy, Sydney: The Federation Press; Anika Gauja (2012) "The "Push" for Primaries: What Drives Party Organisational Reform in Australia and the United Kingdom?', Australian Journal of Political Science 47(4): 641-58; Ingrid van Biezen and Thomas Poguntke (2014) 'The Decline of Membership-Based Politics', Party Politics 20(2): 205-16; Zsolt Enyedi (2014) 'The Discreet Charm of Political Parties', Party Politics 20(2): 194-204.

6 In Western Australia, the Australian Sports Party's primary vote share was 0.23 per cent or 0.016 of a quota. In Victoria, the Australian Motoring Enthusiast Party received 0.51 per cent of primary votes ( 0.0354 of a quota). The result in Western Australia was later declared void due to missing ballot papers. 
needing magnifiers to read large ballot papers, and the difficulty of making an informed choice between a larger number of candidates and parties. ${ }^{7}$

Much of the subsequent commentary on the 2013 election results has centred on the Senate voting system and the ability to 'game' the system through compulsory preferential voting and the use of group voting tickets (GVTs). ${ }^{8}$ As Antony Green has shown, the preferences expressed by minor party voters when voting below the line were very different from the way their preferences were distributed through the GVTs registered by parties. ${ }^{9}$ Less attention has been given to the growth in the number of registered political parties and the impact that the regulatory regime for political parties may be having on democratic participation in Australia. In its inquiry into the 2013 federal election, the JSCEM's interim report focused on Senate voting practices. In regard to the party registration regime, JSCEM recommended changes to minimum membership requirementsto raise the bar against new party entrants contesting electionsbut the role of political parties as forums for promoting political participation remained relatively unaddressed.

\section{Australian microparties}

In the Australian context, 'microparties' can be defined in several ways. The term is usually used in a pejorative sense, often by larger parties that see these minor parties as having a disproportionate influence in relation to their membership, parliamentary size and level of electoral support. Microparties themselves will understandably not use the term for self-identification, and a specific definition can be difficult, but microparties will typically be identified as having small or minimal party membership, low electoral support, low or nonexistent parliamentary representation and a narrow issue-based or ideological policy focus.

\footnotetext{
7 In New South Wales, 44 groups and 110 candidates contested the Senate election.

8 See JSCEM, Interim Report on the Inquiry into the Conduct of the 2013 Federal Election.

9 See Antony Green (2014) 'Below the Line Preference Flows at the 2013 WA Senate Election', ABC Elections, [blog], 4 April, available at: blogs.abc.net.au/antonygreen/2014/04/below-theline-preference-flows-at-the-2013-wa-senate-election.html.
} 
The term microparty is essentially a subjective description of a party that is smaller than a 'minor party'. Typically, a minor party would record a low rating for at least one of the four identifiers - membership base, electoral support, parliamentary representation, policy basebut a microparty could be expected to exhibit low ratings for at least three, if not all four, of the identifiers.

Typically, the microparty may be one or a combination of the following three types. First, the party may be a vehicle for an individual's political aspirations. The formation of these parties is often based on a leader such as an existing Senator or Member of Parliament (MP), and often a parliamentarian who was first elected as a member of another party. This is facilitated by the section 123(1)(a)(i) provision of the Commonwealth Electoral Act 1918 that allows a sole MP or Senator to register a party, with no requirement for a minimum number of party members. Characteristically, these parties rely on the success of the founder, and will often use the founder's name in the registered party name.

The Tasmanian Independent Senator Brian Harradine Group, for instance, existed for 21 years as a support mechanism for Senator Harradine, and was voluntarily deregistered when Harradine retired from parliament. Similarly, the Australian Progressive Alliance (APA) was deregistered after the parliamentary term of its founder, Senator Meg Lees, ended in 2005. Lees had registered the APA in 2003, following her resignation from the Australian Democrats. The 2015 registrations of the Jacqui Lambie Network, Glenn Lazarus Team and John Madigan's Manufacturing and Farming Party are recent examples of this type of microparty. Lambie's and Lazarus' parties were registered following their resignations from the ironically named Palmer United Party, another 'personal' party dependent on its founder-leader for survival. ${ }^{10}$

A second type of microparty is formed to pursue a specific narrow policy agenda. These 'single-issue' parties may be successful in achieving their desired policy outcome simply by competing electorally and not necessarily winning seats. For example, the mere threat of a single-issue

10 Glenn Kefford and Duncan McDonnell (2016) 'Ballots and Billions: Clive Palmer's Personal Party', Australian Journal of Political Science, 5 February, available at: tandfonline.com/doi/full/ 10.1080/10361146.2015.1133800. 
microparty competing at an election may be sufficient for government and opposition parties to adopt a policy position on that particular issue. For instance, in the 2000s, the Fishing Party had some success in influencing changes in major party policies on access for recreational fishing. The ability to use GVTs to direct preferences, either towards or away from these major parties, has given the microparty significant influence. At the very least, the registration of single-issue parties promotes their issues in public political debate.

When single-issue parties are successful in winning seats - for example, the Australian Motoring Enthusiast Party (AMEP) winning a Senate seat in 2013 - the question arises of how these parties' representatives will then act on legislation unrelated to their raison d'être. Although unsuccessful in winning seats, the Save the ADI Site Party (SASP) is an example of the transient nature of some of these single-issue parties. The SASP was registered in 2001 with the primary objective of preventing the development of government-owned bushland near Penrith, in Sydney's western suburbs. The party contested two federal elections, in 2001 and 2004. However, after the Australian Defence Industries (ADI) site was sold to private interests in 2004, the party had no further purpose and was voluntarily deregistered in 2005. ${ }^{11}$ The current register of parties (April 2016) includes many singleissue microparties, such as the Australian Cyclists Party, Australian Antipaedophile Party, Voluntary Euthanasia Party, Smokers Rights Party and Bullet Train for Australia.

The Nick Xenophon Team (NXT) provides a good example of a microparty that exhibits elements of the above types. The NXT has evolved from the Xenophon-led Independent No Pokies ticket, a party grouping that was never registered at the federal level, but played a significant role in South Australian (SA) politics. Xenophon was elected to the SA Parliament in 1997, with less than 3 per cent of the vote, on the single issue of abolishing poker machines. Following his election to the Federal Parliament as an Independent Senator, Xenophon subsequently established the NXT in 2013. From its origins as a single-issue State-based party, the NXT has developed a far broader policy agenda and support base, but primarily remains a vehicle for a single politician.

11 See Norm Kelly (2012) Directions in Australian Electoral Reform: Professionalism and Partisanship in Electoral Management, Canberra: ANU E Press, pp. 85-6. 
A third type of microparty may be formed primarily as a harvester of preferences, often with a 'feel-good' name that can in itself attract votes (for example, Coke in the Bubblers was registered from 2013 to 2015). If several parties established on this basis form a syndicate, their GVTs can distribute their vote preferences within the syndicate. In the Senate context, if there are sufficient syndicate party votes to reach a quota (or at least remain ahead of non-syndicate parties), the lead candidate of one of the syndicate members will be elected.

It appears that the rise in the number of political parties at the federal level has more to do with political expediency, in furthering the interests of a few individuals, than with an increase in broader political participation. This may be for legitimate policy-driven reasons or for personal gain and influence. From a regulatory viewpoint, though, the challenge lies in providing a reasonable balance between allowing the formation of multiple parties to represent diverse policy-based interests and restricting the entry of frivolous or narrowly focused single-issue parties. And there is the prior question of whether this is actually the role of the regulator.

A disconcerting aspect of the increase in prominence of microparties is the deleterious impact it may have on the level of women's representation. Where microparties can win seats (through the lack of a threshold party vote), as in the Australian Senate, this can result in fewer women being elected. This is due to microparties tending to have male leaders who win their only seat. ${ }^{12}$ In the 2013 Victorian Senate election, for instance, only four of 34 minor and microparty leading candidates were women. ${ }^{13}$ This gender disparity was similar in other States.

12 See Richard E. Matland (2005) 'Enhancing Women's Political Participation: Legislative Recruitment and Electoral Systems', in Julie Ballington and Azza Karam (eds) Women in Parliament: Beyond Numbers, Stockholm: International Institute for Democracy and Electoral Assistance, pp. 93-111.

13 Two major party groups, the Coalition and Labor, had male lead candidates. The Greens had a woman lead. 


\section{Promoting and restricting participation}

In the electoral context, participation takes two forms: the internal democratic participation of individuals and organisations within political parties, which can take a variety of different forms, ${ }^{14}$ and the external participation between competing political parties at elections. To date, legislators in Australia have been reluctant to interfere in the internal machinations of parties. As Gauja argues in this volume, this reluctance stems from both a concern to maintain the associated freedoms of parties and a normative disagreement over what might constitute the most appropriate form of intraparty democracy. At the federal level, registered parties are required to have a written constitution that sets out the aims of the party, ${ }^{15}$ but the legislation is otherwise silent on matters to be included in the constitution (for example, administrative structures or governance).

Legislators have usually taken action only after some form of political scandal, with the most obvious example being Queensland's legislation directing the manner in which party preselections are conducted. This general reticence is understandable, as legislators could either be working against the interests of their own parties or, conversely, be overly partisan in their approach. The question of what it means to be a member of a party has not been comprehensively dealt with in legislation. There may be good reason for this and, as Orr points out, under contract law it can be up to the party itself to determine what constitutes a 'member'. ${ }^{16}$ Queensland's Electoral Act provides limited help, saying that a member of a political party means a person who is a member of the political party. ${ }^{17}$ Other jurisdictions do not even include such a concise interpretation.

14 See William P. Cross and Richard S. Katz (eds) (2013) The Challenges of Intra-party Democracy, Oxford: Oxford University Press; Ian Marsh and Raymond Miller (2012) Democratic Decline and Democratic Renewal: Political Change in Britain, Australia and New Zealand, Cambridge: Cambridge University Press.

15 Section 123(1)(b) of the Commonwealth Electoral Act 1918.

16 Graeme Orr (2010) The Law of Politics: Elections, Parties and Money in Australia, Sydney: The Federation Press, pp. 133-4. See also Anika Gauja (2015) 'The Construction of Party Membership', European Journal of Political Research 54(2): 232-48.

17 Section 2 of the Electoral Act 1992. 
Parliaments have been more proactive in regulating the eligibility for parties to fully participate at elections, including party name recognition on ballot papers and public funding. ${ }^{18}$ This may seem to support the cartelisation thesis regarding restriction of competition, ${ }^{19}$ but can also be argued as necessary to ensure voters can make a considered and informed choice between serious candidates and policy options. This rationale is particularly prominent in relation to federal reforms designed to limit the participation of parties such as the Democratic Labor Party (DLP) and Liberals for Forests (LFF). After parliament increased the powers of the Australian Electoral Commission (AEC) to deregister parties in 2000, the DLP refused to provide a membership list to the commission, resulting in parliament further amending legislation in 2001 to strengthen the AEC's powers. ${ }^{20}$ In the LFF case, the Liberal-National Coalition Government was successful in 2004 in legislating to limit the ability for new parties to use names that might misleadingly suggest a connection or relationship with previously registered parties. ${ }^{21}$ However, this could not apply to existing parties, so the government passed further legislation in 2006 to deregister all parties and require them to reapply for registration, thus eliminating the LFF, which had been registered since $2001 .^{22}$

The contestation of ideologically based party names can be seen in the registration process for the Liberal Democratic Party (LDP). The LDP was advised by the AEC in 2007 that the commission would likely reject an application to register the party as the Liberal Democratic Party, due to possible confusion with the existing Liberal Party name. ${ }^{23}$ The party then applied, and was registered, as the Liberty and Democracy Party. The following year, the LDP applied to change its registered name to the Liberal Democratic Party. Despite objections from the Liberal Party, Australian Democrats and the Liberal National Party of Queensland, as well as the AEC's own doubts, the AEC approved the

18 While unregistered parties are able to stand candidates at elections, these candidates have a similar standing as Independent candidates.

19 See Kelly, Directions in Australian Electoral Reform, pp. 24-5.

20 Laurie McGrath (2011) Law Reform and Political Party Registration Case Study: Democratic Labor Party (DLP), Research Paper, Brisbane: Australian Electoral Commission (Queensland), 2 July, available at: aceproject.org/ero-en/regions/pacific/AU/law-reform-and-political-partyregistration-case.

21 Electoral and Referendum Amendment (Enrolment Integrity and Other Measures) Act 2004, amending section 129 of the Commonwealth Electoral Act 1918.

22 Kelly, Directions in Australian Electoral Reform, pp. 97-8.

23 See AEC decision at: aec.gov.au/Parties_and_Representatives/party_registration/Registration_ Decisions/2007/ldp.htm. 
name change. ${ }^{24}$ The result of the 2013 NSW Senate election renewed debate about the consequences of the similarity in the LDP's and Liberal Party's registered names. At that election, the LDP, using their registered short name of 'Liberal Democrats', and fortunate in drawing the first allocated group position on the Senate ballot paper, achieved 9.5 per cent of the vote, ${ }^{25}$ an increase of 7.19 per cent from the 2010 election (when they drew the final group position). The LDP's success in winning a NSW Senate seat can be attributed to the mix of a favourable ballot position, favourable preference flows, possible confusion with the Liberal Party (which used the short name of 'Liberals and Nationals' in a joint ticket in the 25th allocated group) as well as genuine support for the party. The degree of importance attributable to each of these factors, though, is difficult to determine.

\section{Party registration trends}

Prior to 1983, there had been little specific reference to political parties in Australian statutes. Political parties had historically been considered voluntary associations ${ }^{26}$ and the courts were reluctant to interfere in internal party issues. The only pieces of federal legislation that dealt specifically with political parties in the first 80 years of Federation were the Commonwealth Electoral (War-Time) Act 1917, which simply referred to the 'Ministerial' and 'Opposition' parties; the Communist Party Dissolution Act 1950, later ruled by the High Court to be unconstitutional; and the Constitution Alteration (Senate Casual Vacancies) 1977, which facilitated the first reference to political parties in the Australian Constitution.

In more recent times, parties have been more accurately considered as professional organisations that exert considerable influence and power over state affairs, through the election of party candidates, influencing who is elected from other parties or the promotion of policies in an election environment. In addition, since the introduction of public funding regimes in the 1980s, parties have become the recipients

\footnotetext{
24 See AEC decision at: aec.gov.au/Parties_and_Representatives/party_registration/ Registration_Decisions/2008/liberal_democratic.htm.

25 Australian Electoral Commission (AEC) (2010) First Preferences by Candidate: NSW, Virtual Tally Room, Canberra: AEC, available at: results.aec.gov.au/15508/Website/SenateStateFirstPrefs15508-NSW.htm.

26 Anika Gauja (2010) Political Parties and Elections: Legislating for Representative Democracy, Farnham: Ashgate, p. 45.
} 
of substantial taxpayer financial support. As a result, parties have increasingly been considered as legal entities and are increasingly subject to judicial interventions in their affairs. ${ }^{27}$

Since the introduction of the federal registration regime in 1983, 251 parties have been registered at the federal level (for the full list, see the Appendix to this volume). After State divisions and branches of several party groups (such as the Liberal, Labor, Greens and Christian Democratic parties) are consolidated, there remain about 170 specific parties during this 33 -year period. While several parties have re-formed or been renamed over this period, the number of parties registered for each of the 11 elections held since the party registration regime was introduced has ranged from 32 to 77, with at least 50 parties registered at each election since 1990. The focus on the large numbers of Senate groups at the 2013 election has led to a media perception that the 77 parties registered for that election represented a high watermark. However, the same numbers of parties were registered for the 1998 election (see Figure 3.1).

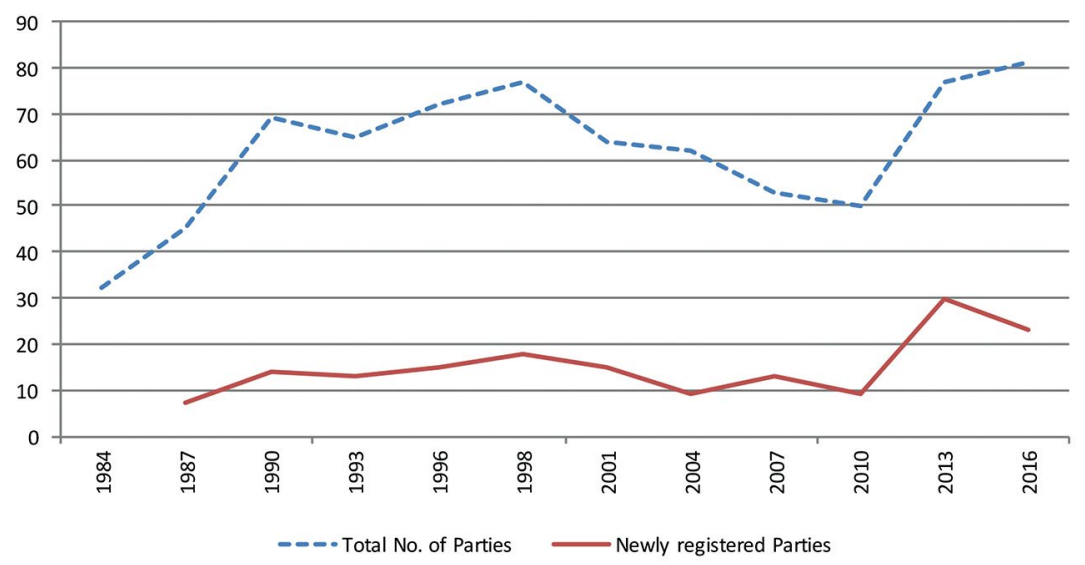

Figure 3.1 Number of registered parties at federal elections, 1984-2013

Notes: Total number of parties includes party divisions as separate parties. Newly registered parties: 1987 does not include seven State and Territory branches of the Australian Labor Party; 1990 does not include 14 State and local Greens parties; 1996 does not include six State and Territory divisions of the Call to Australia (Fred Nile) Group; 1998 does not include nine Christian Democratic parties - essentially a renaming of the Call to Australia Group.

Source: Australian Electoral Commission figures (aec.gov.au).

27 See Orr, The Law of Politics, pp. 117-41. 
When the figures are broken down to identify the number of newly registered parties for each election, it can be seen that there was a significant increase between 2010 and 2013-almost double the number of newly registered parties in any previous inter-election period. Of the 30 newly registered parties, 22 were registered in the eight months prior to the election. ${ }^{28}$ This may suggest an increase in political activism or the setting up of parties for the purpose of 'gaming' the Senate elections (or a combination of both). Since the 2013 election, a further 23 new parties have registered, with many of these likely to be inspired by the 2013 election results.

Table 3.1 Party groups contesting Senate elections, 1998, 2013 and $2016^{\star}$

\begin{tabular}{|l|c|c|c|c|c|c|c|c|c|}
\hline & NSW & Vic. & Qld & WA & SA & Tas. & ACT & NT & Total \\
\hline 1998 & 16 & 19 & 18 & 15 & 10 & 12 & 8 & 5 & 103 \\
\hline 2013 & 42 & 37 & 34 & 27 & 31 & 23 & 13 & 12 & 219 \\
\hline 2016 & 41 & 37 & 37 & 27 & 23 & 21 & 10 & 7 & 203 \\
\hline
\end{tabular}

* Does not include unendorsed groups.

Source: Australian Electoral Commission election results (aec.gov.au).

Further analysis of the 2013 federal election shows that while the total number of parties in 2013 was the same as for the 1998 election, there was a doubling in the number of party nominations for Senate elections (see Table 3.1). This further supports the argument that the Senate voting system was being 'gamed', and is not necessarily an indication of increased political activism. For 2016, there has been only a small drop in the number of party groups contesting the Senate elections. This may indicate that the full effect of changes to the Senate voting system in 2016 is yet to be reflected in party competition. The influence that small parties can have on election outcomes, combined with the ease in harvesting membership names through internet-based and social media sources, suggests that gaming has been a driving factor. However, further analysis is required to determine whether these new parties are a sign of increasing political participation, gaming or possible disenchantment with established, older parties.

Often, these newer small parties have an online presence encouraging people to join, but typically do not provide a link to a party constitution so that this can be considered by intending

28 A list of parties registered between the 2010 and 2013 elections is in the Appendix to this volume. 
members. This includes the Vote Flux Party, Australian Sex Party, AMEP, Australian Christians, Smokers Rights Party and, ironically, the Wikileaks Party - a party with a policy platform based on transparency. The Pirate Party Australia, another freedom of information party, does have its constitution available online. ${ }^{29}$

Analysis of the new parties' websites shows that many of the parties do not require intending members to pay a membership fee (see Appendix 3.1), which can be indicative of a lack of internal party activity and was the case for more than 70 per cent of the parties registered in 2013. On their membership application forms, several parties stress the need to ensure the application details are identical to those on the AEC's roll. ${ }^{30}$ This is clearly designed to ensure that new members can be used to meet the 500-member registration requirement of section 123 of the Act. It appears that many parties are developing their membership simply as a database of enrolled voters, with no requirement to contribute financially to the party and with little opportunity for members to be involved in party activities.

A good example of the motives to establish new parties can be seen from the comments of one promoter of a party seeking registration:

This is intended to be a single issue party, created to hopefully become a balance of power party in the Senate ... I need 500 signatures from people who think as we do, so that I can register the party. ${ }^{31}$

This comment is refreshingly honest and forthright, and highlights the three focuses of many new parties: signatures, a particular single issue and Senate influence. It also emphasises the importance of names and signatures, without mention of participation in internal party activity, such as policy development and campaigning.

This may be a consequence of the federal legislation not specifying requirements to be included in a party's constitution, but may also be in the interests of both a party and its membership. From a party's perspective, managing and organising a membership base can be timeconsuming and costly. And if members have democratic rights-for

29 Available at: pirateparty.org.au/constitution/.

30 For example: 'I declare that I am enrolled on the Commonwealth electoral roll at my address as shown above.'

31 Russell Pridgeon, Australians Against Paedophiles Party, 31 March 2014, available at: hotcopper.com.au/threads/anti-pedophile-party.2250494/?vtrct=5\&utm_expid=509771-17. U3wUhNlPTku4I_iccyMzSg.5\&utm_referrer=https $\% 3 \mathrm{~A} \% 2 \mathrm{~F} \% 2 \mathrm{Fwww}$.google.co.nz $\% 2 \mathrm{~F} \#$. 
example, determining policies and/or executive members - this can be seen as threatening to a party's policy direction and leadership. From a member's perspective, assisting a party to become registered may be considered sufficient political engagement, with no expectation of or desire for further political activism. These can be mutually beneficial outcomes: the party is enabled to pursue its objectives in the electoral and political arenas and can concentrate on these objectives without diverting resources to service the membership, while members have expressed their support for a particular cause, with their activism at a level with which they are comfortable.

An example of this newer form of political activism can be seen in the recently registered Jacqui Lambie Network (JLN). Having been registered on the basis of the provision of the Act that allows a sole MP or Senator to register a party (section 123(1)(a)(i)), the JLN is not required to have 500 members. However, as with other parties, it is seeking electoral success. At the time of writing, the JLN does not have a website and its main interface with the public is a Facebook page. ${ }^{32}$ In principle, a social media site can provide an active interface between a party and its supporters, though one controlled largely by the party itself.

Such forms of party engagement can be more attractive to citizens who may not be interested in the often more formalised structures and processes that exist in many of the older established parties. ${ }^{33}$ While most established parties actively engage in social media to spread their messages and to generate financial support, this tends to support traditional party structures. Newer, smaller parties - for example, those using the section 123 provision-appear to concentrate on forms of 'clicktivism', where supporters are encouraged to click on electronic petitions to demonstrate their political participation. The Glenn Lazarus Team, registered in mid-2015, did not appear to have a party website three months after registration, but, through Senator Lazarus' parliamentary website, supporters could sign petitions, be linked to parliamentary inquiry websites and register for policy forums. The homepage is complete with links to Facebook, Twitter, Instagram

32 Available at: facebook.com/pages/Jacqui-Lambie-Network/881832031874477. Rather than seeking party members, Senator Lambie stated: 'Jacqui Lambie has called for people who would like to be part of her political Network to make contact through her Facebook.' 31 March 2015, available at: senatorlambie.com.au/2015/03/lambie-seeks-to-form-independent-network/.

33 Gauja, 'The Construction of Party Membership'. 
and YouTube, and appears to be designed to provide supporters with easy access to opportunities for political expression, ${ }^{34}$ and this can be particularly appealing to those who distrust established political parties.

\section{The membership threshold}

The difficulty of meeting the 500 -member threshold is reflected in several rejections of party registration applications. In 2013, six applications to register new parties were refused - all due to failure to satisfy the membership threshold test (see Table 3.2). Once the AEC has identified at least 500 names on the electoral roll, it contacts a random sample of 18 to 50 names to ascertain whether they are genuine members of the party. ${ }^{35}$ The majority of parties refused registration (and many that were registered in 2013; see Appendix 3.1) appear to represent extremely narrow policy interests. Typical of these refusals is the rejection of the Cheaper Petrol Party, where the AEC stated that in conducting a random sample of 50 members:

[E]ight of these people denied being members of the Party. Five of the eight people remembered signing a petition for lower petrol prices, but were quite clear that they had not joined a political party and did not want to do so. The other three people had no idea where the Party had sourced their details from and did not remember having any contact with the Party. ${ }^{36}$

Partly as a result of the use of petitions to build membership lists, the JSCEM has recommended that legislation be amended to require the AEC to validate all memberships submitted to meet the minimum membership threshold. ${ }^{37}$ If legislators endorse the recommended trebling of the minimum threshold, the higher level will have little, if any, impact on the major established parties. The increase is designed to eliminate microparties or at least make it difficult for them to survive. A comparison of member threshold requirements in Australian jurisdictions is provided in Table 3.3. When the membership threshold is considered as a ratio against total numbers on the electoral roll,

\footnotetext{
34 See: senatorlazarus.com/.

35 Details of how the numbers are determined are in Appendix 3 of the AEC's Party Registration Guide: Federal Registration of Political Parties booklet, available at: aec.gov.au/Parties_and_ Representatives/Party_Registration/files/party-registration-guide.pdf.

36 Available at: aec.gov.au/Parties_and_Representatives/party_registration/Registration_ Decisions/2013/5204.htm.

37 JSCEM, Interim Report on the Inquiry into the Conduct of the 2013 Federal Election, p. 57.
} 
it can be seen that the federal threshold is the lowest of all Australian jurisdictions, and will remain so even if the threshold was to increase to 1,500 members.

Table 3.2 Parties refused registration in 2013: 500-member test

\begin{tabular}{|l|c|c|c|}
\hline Party & Verified on roll & Contacted & Denied being a member \\
\hline Liberal Movement & 533 & 38 & 12 \\
\hline Cheaper Petrol Party & 549 & 50 & 8 \\
\hline No Parking Meters Party & 502 & 18 & 2 \\
\hline Australian Rock N Roll Party & 419 & 0 & 0 \\
\hline The Burger Urge Party & 500 & 18 & 5 \\
\hline Natural Medicine Party & Not specified & 34 & 4 \\
\hline
\end{tabular}

* The AEC could identify only 489 members of the Natural Medicine Party on the electoral roll from its initial application. A second application was received on 13 June 2013, which was refused due to four people denying being members. A third application was approved in November 2013.

Source: Australian Electoral Commission (www.aec.gov.au/Parties_and_Representatives/ party_registration/index.htm).

Table 3.3 Party membership requirements for registration

\begin{tabular}{|l|c|c|c|c|}
\hline Jurisdiction & $\begin{array}{c}\text { Minimum } \\
\text { required } \\
\text { members }\end{array}$ & $\begin{array}{c}\text { Enrolled at most } \\
\text { recent election } \\
\text { (year) }\end{array}$ & $\begin{array}{c}\text { Enrolled: } \\
\text { minimum required } \\
\text { members ratio }\end{array}$ & $\begin{array}{c}\text { Parties } \\
\text { contesting } \\
\text { most recent } \\
\text { election }\end{array}$ \\
\hline Commonwealth & 500 & $15,671,551(2016)$ & 31,343 & 64 \\
\hline $\begin{array}{l}\text { Commonwealth } \\
\text { (JSCEM } \\
\text { recommendation) }\end{array}$ & 1,500 & $15,671,551(2016)$ & 10,448 & N/A \\
\hline New South Wales & 750 & $5,040,662(2015)$ & 6,721 & 17 \\
\hline Victoria & 500 & $3,806,301(2014)$ & 7,613 & 20 \\
\hline Queensland & 500 & $2,981,145(2015)$ & 5,962 & 7 \\
\hline Western Australia & 500 & $1,412,533(2013)$ & 2,825 & 10 \\
\hline South Australia & 150 & $1,142,419(2014)$ & 7,616 & $22^{2}$ \\
\hline Tasmania & 100 & $366,442(2014)$ & 3,664 & 7 \\
\hline $\begin{array}{l}\text { Australian Capital } \\
\text { Territory }\end{array}$ & 100 & $256,702(2012)$ & 2,435 & 7 \\
\hline Northern Territory & 200 & $123,805(2012)$ & 619 & 5 \\
\hline
\end{tabular}

${ }^{1}$ Separate divisions of a party (for example, Liberal NSW, Victoria; Labor, Country Labor, and so on) or cooperative alliances (for example, Australian Greens, Greens NSW) are counted as one party.

2 Includes eight 'Independent' groups, such as the Nick Xenophon Team and Palmer United Party.

Sources: Electoral commissions' election data, updated from Norm Kelly (2012) Directions in Australian Electoral Reform: Professionalism and Partisanship in Electoral Management, Canberra: ANU E Press, p. 85. 


\section{Regulating for internal party democracy}

A way to encourage greater political participation in political parties is to provide members with genuine opportunities to be involved in decision-making, including for preselections, policy platforms and electing party officials. The existence of a registration regime provides the state with an opportunity to require certain standards or principles of internal party democracy and behaviour. There are competing arguments on whether increased internal party democracy is more empowering for the general party membership or for the party leadership.

For example, Susan Scarrow puts forward the proposition that increased internal democracy can create a 'virtuous circle' whereby the general membership is more closely linked to ordinary citizens and democratic decisions will result in parties better reflecting citizens' views and, as a result, governments become more stable and legitimate. ${ }^{38}$ It is also argued that by including the general membership in decision-making, a party will offer voters more informed choices, as a result of more broad-based input. Conversely, though, the economic theory of democracy argues, as Sawer and Gauja note in Chapter 1, that internal party democracy can detract from a party's ability to be electorally competitive. In such cases, what a party may be seeking are 'fans', as Scarrow describes them: members who are willing to express loyalty and contribute financially, without seeking active involvement in a party's decision-making processes. ${ }^{39}$ Otherwise, ideologically adherent members (again using Scarrow's typology) may stymie electoral effectiveness due to these members being more extremist than the general population.

In Australia, issues of internal party democracy have generally related to candidate preselections, and often in a negative sense following claims of 'branch-stacking' for the purpose of controlling preselection

\footnotetext{
38 Susan Scarrow (2005) Political Parties and Democracy in Theoretical and Practical Perspectives: Implementing Intra-party Democracy, Washington, DC: National Democratic Institute for International Affairs, p. 3.

39 Susan Scarrow (2014) Multi-Speed Membership Parties: Evidence and Implications, Paper prepared for Contemporary Meanings of Party Membership, ECPR Joint Sessions of Workshops, Salamanca, Spain, available at: ecpr.eu/Filestore/PaperProposal/e6c836a5-f1b2-4717-814c786275ce2da2.pdf. Also see Richard Gunther and Larry Diamond (2003) 'Species of Political Parties: A New Typology', Party Politics 9(2): 167-99.
} 
outcomes. For the Australian Labor Party (ALP), internal democracy issues have also related to the election of parliamentary leaders and the degree of voting influence that affiliated trade unions have in preselections. To re-energise the party at the grassroots level, an ALP review committee recommended in 2010 that party executives and trade unions should have less influence in preselections, and that a system of primaries be introduced that would include non-members. ${ }^{40}$

In 2013, ALP members were able to vote in the parliamentary leadership ballot, with the total of members' votes given equal weight with parliamentary party votes. Although Bill Shorten lost the general membership vote ( 40 per cent), he was elected leader due to his high level of support in the caucus room (64 per cent). ${ }^{41}$ The ALP also trialled community preselections ahead of the 2015 NSW State election. ${ }^{42}$ While the concept of a party reaching beyond its membership to make preselection decisions appears to be a healthy democratic development in Australia, it does raise many new regulatory questions. For example, the question of regulating preselection campaign expenditure is an emerging issue.

The most directly democratic of the Australian parties has been the Australian Democrats, which provided all members with a vote on parliamentary leadership positions, preselections, executive positions and policies. This approach, while inherently altruistic, resulted in several problems and issues within the party. For example, through the 1990s, policy positions were often decided by only 1 to 3 per cent of the membership, allowing small numbers of members to exert a large influence on the party's policy positions. ${ }^{43}$ Because of a reliance on mail-based ballots, there can be long periods when the party leadership remains undecided, and leadership votes by the general

40 Steve Bracks, John Faulkner and Bob Carr (2010) 2010 National Review: Report to the ALP National Executive, Canberra: Australian Labor Party.

41 Emma Griffiths (2013) 'Bill Shorten Elected Labor Leader over Anthony Albanese after Month-long Campaign', ABC News, 13 October, available at: www.abc.net.au/news/2013-10-13/ bill-shorten-elected-labor-leader/5019116.

42 In the seats of Balmain, Campbelltown, Londonderry, Newtown and Strathfield. Party members and the general community each receive a 50 per cent vote weighting. Female candidates receive a vote weighting according to Labor's affirmative action policy. See Alexis Carey (2014) 'Former Balmain State Labor MP Verity Firth Wins Community Pre-selection for the Seat of Balmain', Inner West Courier, 5 May, available at: dailytelegraph.com.au/newslocal/innerwest/former-balmain-state-labor-mp-verity-firth-wins-community-pre-selection-for-the-seat-ofbalmain/story-fngr8h4f-1226905718944.

43 Author's personal communications. 
membership can be in conflict with the view of the party's caucus room. For example, in 2001, Senator Natasha Stott Despoja defeated Senator Meg Lees for the party leadership position with about twothirds of the membership vote. However, Stott Despoja did not have majority support in the caucus room and was forced to resign the leadership the following year, while Lees had already left the party.

Currently, when a political party applies for federal registration, it is required to provide a copy of its constitution, but the legislation has limited requirements for what needs to be included in this constitution (see Chapter 7, this volume)..$^{44}$ In 2009, the Rudd Labor Government's Electoral Reform Green Paper put forward a range of measures to regulate party constitutions. The paper suggested that constitutions be available on the AEC website, that they contain minimum requirements in regard to membership, structure and amending the constitution and that they could include internal democracy provisions. ${ }^{45}$ Such reforms had earlier been suggested in the JSCEM's report into the 2004 election. However, internal party democracy was not addressed in the JSCEM report, except in the Australian Democrats' minority report. The Democrats subsequently introduced legislation to require internal democracy measures, but the Bill lapsed without debate in 2010. ${ }^{46}$

At the State level, Queensland has been the only State to legislate for internal party democracy and, as noted earlier, this was a result of concerns of corrupt and fraudulent practices within parties. ${ }^{47}$ Following amendments in 2002, the Electoral Act 1992 is now quite prescriptive of what is required in a registered party's constitution, including that a preselection ballot must satisfy the general principles of free and democratic elections. ${ }^{48}$ The following subsection details what these principles are, including that only party members may vote, each member has only one vote and voting is to be conducted by secret ballot. Further, Electoral Commission Queensland (ECQ) can intervene in a party's preselection processes, either on its own initiative

44 Section 126(2)(f) of the Commonwealth Electoral Act 1918.

45 Australian Government (2009) Electoral Reform Green Paper: Strengthening Australia's Democracy, Canberra: Commonwealth of Australia, p. 117.

46 Electoral (Greater Fairness of Electoral Processes) Amendment Bill 2007.

47 Scott Bennett (2002) Australia's Political Parties: More Regulation?, Department of the Parliamentary Library Research Paper No. 21, Canberra: Parliament of Australia, p. 20.

48 Section 76(1) of the Electoral Act 1992. 
or after receiving a complaint. ${ }^{49}$ Section 71 of New Zealand's Electoral Act 1993 contains similar provisions for member participation in preselections, including an allowance for preselections to be decided by delegated authority.

\section{JSCEM recommendations}

The reforms of 1983 were designed to provide the major parties with control over the Senate voting system. Although the rising level of informal voting for the Senate had been a catalyst for change, the possibility existed to reform the system without removing voters' control over the flow of their preferences. In 1983, the ALP recommended the introduction of optional preferential voting (OPV) for both the Senate and the House of Representatives. The (Labor-majority) Joint Select Committee on Electoral Reform (JSCER) noted that:

[T] he full preferential system leads to an increased informal vote, and may force voters to cast a preference in favour of candidates to whom they feel antipathy, or feel no sympathy, or about whom they do not care. ${ }^{50}$

However, the Liberal-National Coalition opposed Labor's OPV proposal. This was understandable given that the Coalition was the major beneficiary of preference flows at the time. The proposal was therefore abandoned in the desire to achieve broader bipartisan reform.

In May 2014, the (Coalition-majority) JSCEM released an interim report into the 2013 election and reprised the comment from the 1983 committee that 'electors felt their votes had been devalued by preference deals and that they had been disenfranchised by being forced to prefer unpreferred candidates' ${ }^{51}$ The 2014 report recommended that OPV be introduced for above-the-line voting and that GVTs be abolished. While the JSCEM report supported this recommendation by making reference to the altruistic ideals of 'enfranchising voters by returning to them full control of preferences' and 'ending voter frustration',

\footnotetext{
49 ibid., s. 168.

50 Joint Select Committee on Electoral Reform (JSCER) (1983) First Report, Canberra: Parliament of the Commonwealth of Australia, p. 63.

51 JSCEM, Interim Report on the Inquiry into the Conduct of the 2013 Federal Election, p. 2.
} 
it also referred to the political objectives of providing a disincentive to the proliferation of 'minor "front" parties' and 'removing the incentive to "game" the system". ${ }^{52}$

Once again, the approach to possible reform was influenced by perceptions of electoral advantage from the existing system - with the Coalition Government in the midst of negotiating legislation through a noncompliant Senate at the time, due to the balance of power held by the microparties. It was therefore seen as electorally and politically advantageous to remove these microparties. The difficulty with this strategy is that the Coalition requires support from one of the larger parties - the ALP or The Greens - to bring about change, as the microparties will be steadfast in opposing any reform that is likely to result in their demise. ${ }^{53}$

Between the 1983 and 2014 reports, the (Coalition-majority) JSCEM report on the 1996 election stated it would prefer reducing the number of candidates standing for the Senate, to moving to an OPV system. However, since that report, Senate candidate numbers have more than doubled (see Table 3.4) and the JSCEM was largely silent on this issue until its 2014 report.

Table 3.4 Candidates contesting Senate elections, 1983-2016

\begin{tabular}{|c|c|c|c|c|c|c|c|c|c|c|c|c|}
\hline 1983 & 1984 & 1987 & 1990 & 1993 & 1996 & 1998 & 2001 & 2004 & 2007 & 2010 & 2013 & 2016 \\
\hline $244^{\star}$ & 202 & $255^{\star}$ & 223 & 266 & 255 & 329 & 285 & 330 & 367 & 349 & 529 & $631^{\star}$ \\
\hline
\end{tabular}

* 1983, 1987 and 2016 were double-dissolution elections, meaning that all Senate seats were up for election, resulting in higher than normal numbers of candidates.

Source: Australian Electoral Commission election results (aec.gov.au).

The 2014 report contained only three core recommendations in relation to party registration: increase the membership threshold to 1,500 members, with lower thresholds for parties that wish to nominate candidates only in specific States or Territories; require new and existing parties to meet the new thresholds; and require more

52 ibid., p. 52.

53 See Lenore Taylor (2015) 'Turnbull Government Faces Battle to Change Voting Rules for Senate', The Guardian, 22 September, available at: theguardian.com/australia-news/2015/ sep/22/turnbull-government-faces-battle-to-change-voting-rules-for-senate; and Heath Aston (2015) 'Micro-parties Threaten Election War against Coalition, Greens over Senate Change', The Canberra Times, 23 September, available at: canberratimes.com.au/federal-politics/ political-news/microparties-threaten-election-war-against-coalition-greens-over-senate-change20150923-gjt29b.html. 
detail in party constitutions. While this is a minimalist approach to an opportunity to overhaul the registration regime, it is understandable given that the inquiry was primarily focused on the Senate election outcomes and possible 'gaming' of the system.

As part of its recommendations, JSCEM proposed that the AEC check the membership validity of each person submitted to meet the threshold and that these verification checks be conducted for each party every three years. If this provision were to be adopted, along with the accompanying recommendation to increase the minimum membership threshold to 1,500 , this would create a significantly higher administrative burden on the AEC. This would be met from central funds, but the JSCEM has also recommended that there should not be any increase in the cost to apply for registration (currently $\$ 500$ ). Hence, there is little monetary penalty for party applicants to ensure their membership lists are accurate; it is the AEC that has the financial burden of verifying applications. A better system may be to increase the application fee substantially, with the major proportion of the fee refunded once a party is registered. This would provide all parties with a severe penalty if their membership lists were noncompliant.

The JSCEM recommendation to require parties to provide more detail in their constitutions is based on the Queensland legislation, with details required including party objectives, rules of membership, selection of officials and preselection rules. ${ }^{54}$ This appears to be a common sense approach, not dictating to parties how to run their affairs, but requiring information that is beneficial to intending members. Ideally, this would create greater transparency in relation to internal processes, while leaving it to the parties to decide the manner in which these issues are dealt with - a natural progression in the way that party administration has evolved from the private to the public realm.

54 JSCEM, Interim Report on the Inquiry into the Conduct of the 2013 Federal Election, pp. 58-9. 


\section{6: Reform at last}

In March 2016, reform of the Senate voting system was passed by the Parliament. ${ }^{55}$ These changes did little in the area of party registration, with the primary change being to allow the use of party logos on ballot papers - partially a response to questions of confusion for voters, as discussed earlier in relation to the LDP. Two major reforms of the voting system occurred. First was the removal of voting tickets, therefore removing the ability for parties to direct the preferences of voters. Second, partial optional preferential (POP) voting for the Senate was introduced, so that voters now only need to express six preferences above the line or 12 below the line to make a formal vote. ${ }^{56}$ Now that voters no longer have the convenience of stating a single preference, POP voting eases the burden for the voter that a full preferential system would create. This also avoids the complexity and high informal rate that would most likely occur under a full preferential system.

The Coalition Government was able to pass the legislation with the support of the Australian Greens, a party that would also benefit from the reduced influence, and seat-winning ability, of the microparties. Although there may be strategic advantages to The Greens, the party also has a significant history of Senate electoral reform attempts, so their actions in 2016 can be viewed as a convergence of party policy and pragmatic positioning. The reaction from the microparties was understandable, with arguments that, for example, the reform 'strips democracy from the people'57 and 'will crucify democracy in this country'.$^{58}$ However, the microparties are essentially victims of their own success and their arguments are not consistent with the democratic principle of fairness. Despite any strategic reasons the Coalition and

55 Commonwealth Electoral Amendment Bill 2016.

56 There are additional saving provisions to ensure that voters who continue to use the previous system - that is, just voting ' 1 ' above the line - will have this recorded as a formal vote. See the explanatory memoranda, available at: aph.gov.au/Parliamentary_Business/ Bills_ Legislation/Bills_Search_Results/Result?bId=r5626.

57 Senator Ricky Muir (2016) Hansard, 17 March, p. 2328.

58 Senator Glenn Lazarus (2016) Hansard, 16 March, p. 2232. 
Greens may have for the reforms, the reality is that, as Antony Green states, 'it is fairer as [the reform places] the power over preferences into the hands of voters'.$^{59}$

\section{Conclusions}

The founders of the microparties that have been registered in recent years cannot be blamed for engaging in their strategic manoeuvres to win Senate seats at the 2013 election. They achieved success by forming syndicates that worked together to exploit the weaknesses in the system designed by their political opponents. In this setting, the microparties have exhibited more astute strategic positioning and agility than the older governing parties that established and maintained this electoral environment over the past 30 years. The Labor/Coalition governing parties' cartel has failed to reform a flawed voting system, despite its weaknesses being obvious for many years. The major governing parties are the ones who have controlled the outputs of the JSCEM over the past 30 years, and who are responsible for creating this situation. Because these microparties gained seats in the Senate, it became difficult for the government to amend the Senate voting system in a way that would disadvantage these microparties, at least until a willing ally in the Senate was found.

A benefit of the increased number and influence of microparties has been the prominent attention given to several narrow policy areasfor instance, the interests of motoring enthusiasts appear to be well served by the election of the AMEP's Ricky Muir to the Senate. However, the increase in the number of registered parties since 2010 has not been in response to public demand for new outlets for political activism and political expression. And while the 1983 reforms were designed to encourage stronger parties, it was never a specific intent of the legislation to promote participation.

Party defections have occurred since the 2013 election, with newly Independent Senators Lambie, Lazarus and Madigan now forming their own microparties through the section 123(1)(a)(i) provision of the

59 Antony Green (2016) 'Q\&A: Open Post for Questions on the New Senate Electoral System', $A B C$ Elections, [blog], 9 March, available at: blogs.abc.net.au/antonygreen/2016/03/qa-openpost-for-questions-on-the-new-senate-electoral-system.html. 
Act. This provision negates any sense that the 1983 legislative reforms may have been designed to promote political participation, though founders of these parties may argue that they are filling an unmet need in political debate. The 'single-member' party is one that needs neither party membership support nor substantial levels of voter support to survive. The control of GVT preference flows - in both receiving and dispersing these preferences - has allowed these parties to wield significant influence, far in excess of their levels of member or voter support.

The 2016 Senate voting system reform package is a positive outcome for democratic choice. The removal of voting tickets and, to a lesser extent, the introduction of POP voting above the line, shift power away from party brokers. These preference dealers, from both major and smaller parties, have controlled voters' preferences as a result of the difficulty voters had in expressing their own choices. Now voters are able to exercise the power - and the responsibility - to indicate their own preferences.

The 2016 general election provides an interesting case study of the response to electoral reform in terms of how parties reacted to these changes through their campaigning techniques and how-to-vote card designs. Voters appear to have embraced this newfound level of direct influence over election outcomes by shifting away from the major parties, with record numbers of voters supporting minor parties and Independents in both the House of Representatives and Senate.

\section{Appendix 3.1: New party registrations, 2010-16}

Table A3.1 Parties registered between the 2010 and 2013 federal elections

\begin{tabular}{|l|l|c|}
\hline Registration & Party & $\begin{array}{c}\text { Membership } \\
\text { fee (\$) }\end{array}$ \\
\hline 23 September 2010 & Stable Population Party of Australia & 20 \\
\hline 23 September 2010 & Help End Marijuana Prohibition (HEMP) Party & 0 \\
\hline 6 January 2011 & The First Nations Political Party & $?$ \\
\hline 18 January 2011 & Australian Protectionist Party & 20 \\
\hline 3 May 2011 & Animal Justice Party & 20 \\
\hline 26 July 2011 & Country Alliance & 30 \\
\hline
\end{tabular}




\begin{tabular}{|c|c|c|}
\hline Registration & Party & $\begin{array}{l}\text { Membership } \\
\text { fee (\$) }\end{array}$ \\
\hline 27 September 2011 & Katter's Australian Party & 33 \\
\hline 15 December 2011 & Australian Christians & 20 \\
\hline 3 February 2012 & Rise Up Australia & 20 \\
\hline 15 January 2013 & Pirate Party Australia & 20 \\
\hline 21 February 2013 & Bank Reform Party & 0 \\
\hline 20 March 2013 & $\begin{array}{l}\text { Carers Alliance (re-registration) (originally } \\
\text { registered in 2007, deregistered in 2012) }\end{array}$ & 0 \\
\hline 22 May 2013 & Bullet Train for Australia & 0 \\
\hline 5 June 2013 & Uniting Australia Party & $?$ \\
\hline 1 July 2013 & Nick Xenophon Team & $?$ \\
\hline 1 July 2013 & Voluntary Euthanasia Party & 0 \\
\hline 1 July 2013 & The Wikileaks Party & 20 \\
\hline 2 July 2013 & Australian Sovereignty Party & 0 \\
\hline 2 July 2013 & Australian Voice Party & 30 \\
\hline 2 July 2013 & Drug Law Reform Australia & 0 \\
\hline 2 July 2013 & Future Party & 0 \\
\hline 2 July 2013 & The 23 Million & 0 \\
\hline 5 July 2013 & Palmer United Party & 20 \\
\hline 5 July 2013 & Outdoor Recreation Party (Stop The Greens) & 0 \\
\hline 9 July 2013 & Australian Motoring Enthusiast Party & 20 \\
\hline 9 July 2013 & Australian Sports Party & 0 \\
\hline 9 July 2013 & Republican Party of Australia & 0 \\
\hline 16 July 2013 & Coke in the Bubblers Party & 0 \\
\hline 16 July 2013 & Smokers Rights Party & 0 \\
\hline 16 July 2013 & Australian Independents & 0 \\
\hline 23 July 2013 & Stop CSG Party & 0 \\
\hline
\end{tabular}

Source: Australian Electoral Commission (www.aec.gov.au/Parties_and_Representatives/ party_registration). Membership fees as provided on party websites.

Table A3.2 Parties that applied prior to the 2013 election and registered after the 2013 election

\begin{tabular}{|l|l|c|}
\hline Registration & Party & Membership fee (\$) \\
\hline 7 November 2013 & 21st Century Party & 0 \\
\hline 7 November 2013 & Single Parents' Party & 0 \\
\hline 7 November 2013 & Natural Medicine Party & 20 \\
\hline
\end{tabular}

Source: Australian Electoral Commission (www.aec.gov.au/Parties_and_Representatives/ party_registration). Membership fees as provided on party websites. 
PARTY RULES?

Table A3.3 Newly registered parties, 2014-16

\begin{tabular}{|c|c|c|}
\hline Registration & Party & Membership fee (\$) \\
\hline 6 August 2014 & The Arts Party & 20 \\
\hline 20 August 2014 & Australian Cyclists Party & 0 \\
\hline 9 October 2014 & Australian Equality Party & 30 \\
\hline 17 February 2015 & Australian Progressives & 0 \\
\hline 4 March 2015 & Seniors United NSW & 20 \\
\hline 14 May 2015 & Jacqui Lambie Network & $?$ \\
\hline 18 May 2015 & $\begin{array}{l}\text { John Madigan's Manufacturing and } \\
\text { Farming Party }\end{array}$ & 0 \\
\hline 15 June 2015 & Australian Defence Veterans Party & 50 \\
\hline 9 July 2015 & Glenn Lazarus Team & 0 \\
\hline 28 July 2015 & Australians Against Paedophiles Party & 0 \\
\hline 28 July 2015 & Australian Liberty Alliance & 10 \\
\hline 25 February 2016 & The Australian Greens -Victoria & $30 / 135^{\star}$ \\
\hline 7 March 2016 & Consumer Rights \& No-Tolls & 0 \\
\hline 11 March 2016 & The Australian Mental Health Party & 0 \\
\hline 22 March 2016 & Renewable Energy Party & 0 \\
\hline 29 March 2016 & $\begin{array}{l}\text { VOTEFLUX.ORG | Upgrade } \\
\text { Democracy! }\end{array}$ & 0 \\
\hline 14 April 2016 & Mature Australia Party & 30 \\
\hline 14 April 2016 & Derryn Hinch's Justice Party & 20 \\
\hline 14 April 2016 & CountryMinded & 0 \\
\hline 9 May 2016 & Australian Recreational Fishers Party & 10 \\
\hline
\end{tabular}

Source: Australian Electoral Commission (www.aec.gov.au/Parties_and_Representatives/ party_registration). Membership fees as provided on party websites.

* Scaled, depending on income. 
This text is taken from Party Rules?: Dilemmas of political party regulation in Australia, edited by Anika Gauja and Marian Sawer, published 2016 by ANU Press, The Australian National University,

Canberra, Australia. 